\title{
Effect of Metal Chelators on $\gamma$-Secretase Indicates That Calcium and Magnesium Ions Facilitate Cleavage of Alzheimer Amyloid Precursor Substrate
}

\author{
Michael Ho, ${ }^{1}$ David E. Hoke, ${ }^{1,2}$ Yee Jia Chua, ${ }^{1}$ Qiao-Xin Li, ${ }^{1,3}$ Janetta G. Culvenor, ${ }^{1,4}$ \\ Colin Masters, ${ }^{3}$ Anthony R. White, ${ }^{1,4}$ and Geneviève Evin ${ }^{1,3}$ \\ ${ }^{1}$ Department of Pathology, The University of Melbourne, Parkville, VIC 3010, Australia \\ ${ }^{2}$ Department of Biochemistry and Molecular Biology, Monash University, Clayton, VIC 3800, Australia \\ ${ }^{3}$ Mental Health Research Institute, The University of Melbourne, Parkville, VIC 3052, Australia \\ ${ }^{4}$ Centre for Neuroscience, The University of Melbourne, Parkville, VIC 3010, Australia
}

Correspondence should be addressed to Geneviève Evin, gmevin@unimelb.edu.au

Received 15 September 2010; Revised 22 November 2010; Accepted 25 November 2010

Academic Editor: Peter Faller

Copyright () 2011 Michael Ho et al. This is an open access article distributed under the Creative Commons Attribution License, which permits unrestricted use, distribution, and reproduction in any medium, provided the original work is properly cited.

Gamma-secretase is involved in the production of $\mathrm{A} \beta$ amyloid peptides. It cleaves the transmembrane domain of the amyloid precursor protein (APP) at alternative sites to produce A $\beta$ and the APP intracellular domain (AICD). Metal ions play an important role in $\mathrm{A} \beta$ aggregation and metabolism, thus metal chelators and ligands represent potential therapeutic agents for $\mathrm{AD}$ treatment. A direct effect of metal chelators on $\gamma$-secretase has not yet been investigated. The authors used an in vitro $\gamma$-secretase assay consisting of cleavage of APP C100-3XFLAG by endogenous $\gamma$-secretase from rodent brains and human neuroblastoma SH-SY5Y, and detected AICD production by western blotting. Adding metalloprotease inhibitors to the reaction showed that clioquinol, phosphoramidon, and zinc metalloprotease inhibitors had no significant effect on $\gamma$-secretase activity. In contrast, phenanthroline, EDTA, and EGTA markedly decreased $\gamma$-secretase activity that could be restored by adding back calcium and magnesium ions. $\mathrm{Mg}^{2+}$ stabilized a 1,000 kDa presenilin 1 complex through blue native gel electrophoresis and size-exclusion chromatography. Data suggest that $\mathrm{Ca}^{2+}$ and $\mathrm{Mg}^{2+}$ stabilize $\gamma$-secretase and enhance its activity.

\section{Introduction}

Gamma-secretase is a key protease activity involved in the production of Alzheimer's disease $\mathrm{A} \beta$ amyloid peptides and in regulated intramembrane processing of a subset of membrane receptors, including Notch (reviewed in [1]). A $\beta$ is proteolytically derived from the type I integral amyloid precursor protein (APP) [2] by two sequential cleavages. Shedding of the large APP ectodomain by $\beta$-secretase $(\beta$ APP cleaving enzyme1, BACE1) [3] produces a 99 amino acid membrane-tethered stub ( $\beta$-secretase generated APP Cterminal fragment, $\beta$ CTF, or C99) that is further processed by $\gamma$-secretase to liberate $\mathrm{A} \beta$ peptides in the extracellular/luminal space. $\gamma$-Secretase cleaves the transmembrane domain of APP at multiple sites. Cleavage at the $\varepsilon$-site [4], at position 49-50 according to numbering from $\mathrm{A} \beta \mathrm{N}$-terminus mediates the cytosolic release of APP intracellular domain (AICD) together with its binding partners and regulates their nuclear translocation [5]. Further cleavages at the $\zeta /(46-47)$ and $\gamma /(40-41)$ sites generate $\mathrm{A} \beta_{40}$ [6]. Pathogenic mutations in APP or in the presenilins result in shifting of $\varepsilon$-cleavage to the (48-49) site and production of $\mathrm{A} \beta_{42}$ [7]. APP also undergoes ectodomain shedding by cleavage within the $\mathrm{A} \beta$ domain by $\alpha$-secretase, in a nonamyloidogenic cellular pathway, followed by $\gamma$-secretase processing of the corresponding membrane stub (C83) to release AICD and a p3 fragment (reviewed in [8]).

$\gamma$-Secretase activity is contained within high molecular complexes formed by assembly of four integral membrane proteins, presenilin, nicastrin, Aph-1, and Pen-2 [9]. Gene knockout experiments [10] and mutation of two conserved aspartates [11] have revealed that the presenilins, 
either PS1 or PS2, are membrane proteases and constitute the catalytic subunits of $\gamma$-secretase complexes.

The mechanism of $\gamma$-secretase and its modulation are yet to be elucidated. We aimed to investigate the effect of metal chelators on $\gamma$-secretase activity in vitro. Indeed, biometals and metalloenzymes play an important role in the metabolism of APP and A $\beta$. APP itself comprises two zinc/copper binding sites, one of them located within the $\mathrm{A} \beta$ sequence [12-14]. Although the precise function of APP remains unclear, a wealth of experimental evidence indicates that it plays a role in copper homeostasis [15]. The reduction of $\mathrm{Cu}^{2+}$ to $\mathrm{Cu}^{+}$by APP is accompanied by the production of hydrogen peroxide resulting in oxidative stress [16]. Also, metal ions, particularly copper, mediate $\mathrm{A} \beta$ oligomerization and toxicity [17], therefore metal chelators and ionophores are currently being evaluated as drug candidates for $\mathrm{AD}$ treatment (reviewed in [18]). To support the merit of this therapeutic approach, the copper chelator clioquinol (CQ) has been shown to reduce $\mathrm{A} \beta$ deposition in the brain of an AD transgenic mouse model [19].

Metals are also implicated in $\mathrm{A} \beta$ clearance as the enzymes that metabolize $\mathrm{A} \beta$ peptides are zinc-dependent (for a complete review, see [20]), in particular the insulindegrading enzyme (IDE) [21-24], neprilysin (NEP) [2527], and the matrix-metalloproteinases MMP2 and MMP9 [28-30]. Secretase processing of APP is also influenced by metal ions since the $\alpha$-secretase enzymes belong to the family of ADAM proteases, which are zinc-metalloproteases [31], and the $\beta$-secretase enzyme; BACE1 comprises a copperbinding site within its cytoplasmic tail, which may regulate its enzymatic activity [32].

In this paper, we have evaluated the direct effects of metal chelators on $\gamma$-secretase in an in vitro assay using endogenous enzyme extracted from guinea pig and mouse brains, or from human neuroblastoma SH-SY5Y cells, together with C1003XFLAG substrate, an analogue of APP $\beta$-CTF.

\section{Materials and Methods}

2.1. Materials and Reagents. Adenosine $5^{\prime}$-triphosphate disodium salt (ATP), ethylene glycol-bis[2-aminoethyl ether]$\mathrm{N}, \mathrm{N}, \mathrm{N}^{\prime}, \mathrm{N}^{\prime}$-tetraacetic acid (EGTA), glycerol, 5-chloro7-iodo -8-hydroxyquinoline (clioquinol or CQ), D,L-thiorphan, P2714 protease inhibitor cocktail, [3-[(3-cholamidopropyl)dimethylammonio-]-2-hydroxy-1-propanesulfonate] (CHAPSO), M2 monoclonal antibody, and anti-FLAG M2agarose were purchased from Sigma-Aldrich (Sydney, Australia). Glycerol, phosphoramidon and 1,10-phenanthroline were from Merck Biosciences (Victoria, Australia). GM6001 (ilomastat) was obtained from Chemicon (Boronia, Victoria, Australia). L-685,458 inhibitor was obtained from Dr. Mark Shearman (Merck, Sharpe, and Dohme).

2.2. C100-3XFLAG Preparation and Purification. E. Coli transformed with the C100-3XFLAG vector were grown and induced for C100-3XFLAG expression as described before [33]. The cells were harvested, resuspended in $50 \mathrm{mM}$ HEPES, $5 \mathrm{mM} \mathrm{MgCl}_{2}, 5 \mathrm{mM} \mathrm{CaCl}_{2}, 150 \mathrm{mM} \mathrm{KCl}$, and $\mathrm{pH}$
7.4, supplemented with $1 \%(\mathrm{w} / \mathrm{v})$ P-2714 (Sigma) protease inhibitor cocktail, and disrupted by sonication. Membranes were isolated by centrifugation for 1 hour at $100,000 \mathrm{~g}$, and were resuspended in homogenisation buffer containing $1 \%(\mathrm{v} / \mathrm{v})$ CHAPSO, using a Dounce homogenizer, followed by repeated passages through syringe needles of decreasing bore size. The resultant fine suspension was incubated for 1 hour at $4^{\circ} \mathrm{C}$, with end-over-end rocking, then centrifuged at $18,000 \mathrm{~g}$ for 1 hour at $4^{\circ} \mathrm{C}$, and the supernatant containing the solubilized proteins was brought up to $10 \%$ glycerol (v/v). C100-3FLAG was affinity-purified on anti-FLAG M2agarose column and the purified substrate was stored as aliquots at $-80^{\circ} \mathrm{C}$.

2.3. Preparation of $\gamma$-Secretase Activity. All steps were carried out on ice and the centrifugation steps done at $4^{\circ} \mathrm{C}$. Guinea pigs and mouse $(\mathrm{C} 57 / \mathrm{Bl} 6)$ brains were obtained from the Animal Facility of the University of Melbourne Department of Pathology as secondary tissue usage of excess animals. Homogenates from whole brains, minus cerebellum, were prepared as described previously [33]. The crude tissue homogenate prepared in $20 \mathrm{mM}$ HEPES, pH 7.4, containing $250 \mathrm{mM}$ sucrose, and 1\% protease inhibitor cocktail (with no pepstatin), was centrifuged at 3,000 g for 30 minutes to remove cellular debris. The supernatant was collected and centrifuged further at $100,000 \mathrm{~g}$ for 1 hour in a L8-80M ultracentrifuge equipped with a Ti70.1 rotor (BeckmanCoulter). The pellet was washed with $20 \mathrm{mM}$ HEPES, $150 \mathrm{mM} \mathrm{KCl}$, and $\mathrm{pH}$ 7.4, and resuspended in the same buffer plus $1 \%(\mathrm{v} / \mathrm{v})$ CHAPSO, with mixing on a rotating platform for 1 hour, at $4^{\circ} \mathrm{C}$. CHAPSO-extracted membranes were removed by centrifugation at $18,000 \mathrm{~g}$ for 20 minutes The supernatant, containing solubilized $\gamma$-secretase, was brought up to $10 \%$ glycerol $(\mathrm{v} / \mathrm{v})$, and stored as aliquots at $-80^{\circ} \mathrm{C}$.

Alternatively, SH-SY5Y cells were resuspended in $20 \mathrm{mM}$ HEPES, $80 \mathrm{mM} \mathrm{KCl}$, and $\mathrm{pH} 7.3$, supplemented with $1 \%$ protease inhibitor cocktail, and homogenized by repeated passages through a 25-gauge needle. The cell homogenate was centrifuged at 1,000 g for $20 \mathrm{~min}$ to remove nuclei and cell debris. The resultant supernatant was collected and centrifuged for 1 hour at 100,000 g. The sediment pellet was extracted with $1 \%$ CHAPSO.

2.4. Gamma-Secretase Assays. Purified recombinant substrate $(\sim 1.5 \mu \mathrm{M})$ and CHAPSO-solubilized membranes $(5 \mu \mathrm{g}$ of guinea pig or mouse brain preparation, or $15 \mu \mathrm{g}$ of SH-SY5Y membrane extract) were incubated for 4 to 18 hours at $37^{\circ} \mathrm{C}$ in presence of ATP $(1.25 \mathrm{mM})$ and a mixture of phosphotidyl-ethanolamine (PE) and phosphotidylcholine (PC) (50 ng each; Sigma-Aldrich) in a final reaction volume of $20 \mu \mathrm{L}$ of $20 \mathrm{mM}$ HEPES ( $\mathrm{pH} 7.4)$ and $0.5 \%$ CHAPSO, plus either $2 \mathrm{mM}$ EDTA (buffer E) or $5 \mathrm{mM} \mathrm{CaCl}_{2}, 5 \mathrm{mM} \mathrm{MgCl}$ and $150 \mathrm{mM} \mathrm{KCl}$ (buffer A). Inhibitors were prepared as stocks in DMSO and used at dilutions so that DMSO concentration in incubations was no more than $2.5 \%$. Incubations were terminated by adding Laemmli SDS sample buffer and heating at $95^{\circ} \mathrm{C}$ for 5 minutes. The samples were electrophoresed for 5 hours on 
Tris-tricine gels (two-layer, 10-15\% acrylamide discontinuous gradient) using a miniPROTEAN 3 system (Bio-Rad) followed by electrotransfer to nitrocellulose (Trans-blot, Bio$\mathrm{Rad})$. The blots were boiled in phosphate buffer saline, $\mathrm{pH}$ 7.4 (PBS) for 3 min prior to blocking for 1 hour with $0.5 \%$ casein in PBS and probing with primary antibody for 2 hours. The blots were developed with the Super Signal West Dura kit (Pierce, Rockford, Il) and exposed to a GeneGnome digital imaging system (Syngene, Cambridge, UK). Data were analysed using GeneTools software (Syngene). $\gamma$-Secretase activity was expressed as the ratio of AICD signal to the sum of C100 plus AICD signals after subtracting blank values. $\mathrm{A} \beta$ was quantified by DELFIA as described before [34]. In brief, plates were coated with mouse monoclonal antibody G210 (specific for $\mathrm{A} \beta_{40}$ ) and developed with biotinylated WO2 (anti-A $\beta$ 1-16). Bound antibody was detected with streptavidin-labeled Europium (Perkin Elmer, Inc, Melbourne, Victoria). Results were calculated from a standard curve obtained with $\mathrm{A} \beta_{40}$ synthetic peptide.

2.5. BN-PAGE Analysis. SH-SY5Y membrane extract (0.5\% CHAPSO), prepared as described above, was mixed with an equal volume of $20 \mathrm{mM}$ HEPES ( $\mathrm{pH} 7.4$ ) containing $0.5 \%$ CHAPSO plus one of the following, $2 \mathrm{mM}$ EDTA, $2 \mathrm{mM}$ EGTA, $5 \mathrm{mM} \mathrm{MgCl}_{2}$, or $5 \mathrm{mM} \mathrm{CaCl}_{2}$, and incubated for 18 hours at $19^{\circ} \mathrm{C}$. BN-PAGE sample buffer was added and the samples resolved on 3-8\% NuPAGE Tris-acetate gels (Invitrogen) as described previously [35].

2.6. Size-Exclusion Chromatography. SH-SY5Y membrane extracts (diluted to $0.5 \%$ CHAPSO) prepared as for BNPAGE were fractionated on a Superose-6 column (GE Healthcare) equilibrated in $20 \mathrm{mM}$ HEPES, $150 \mathrm{mM} \mathrm{KCl}$ buffer, and $\mathrm{pH} 7.3$ and eluted at a flow rate of $0.5 \mathrm{~mL} / \mathrm{min}$. $0.5 \mathrm{~mL}$ fractions were collected and analysed by western blotting with $98 / 1$ antibody [36].

\section{Results}

3.1. In Vitro $\gamma$-Secretase Assay. C100 substrate, expressed in E. coli, is based on the human APP C-terminal sequence, which corresponds to the $\mathrm{C}$-terminal fragment produced by $\beta$-secretase cleavage of APP $(\beta$-CTF, the direct precursor to $A \beta)$ plus $\mathrm{N}$-terminal Met 596 . C100 is expressed with a 3XFLAG C-terminal tag to improve solubility, stability, and detection of AICD [33]. Incubations of C100-3XFLAG with $\gamma$-secretase preparations from guinea pig brain membranes produced a $10 \mathrm{kDa}$ C-terminal fragment that was inhibited in a dose-response manner by two specific $\gamma$-secretase inhibitors, L-685,458 [37], and DAPT [38] (Figure 1(a)). AICD production was time dependent (Figure 1(b)). Detection of $\mathrm{A} \beta$ with $\mathrm{WO} 2$ shows an increased production between 2 and 4 hours but the results could not be quantified due to high background and merging of the bands between the lanes.

The effects of phospholipids and ATP were tested to further validate the AICD detection assay and optimize conditions. Adding phospholipids (PC and PE, $2.5 \mu \mathrm{g} / \mathrm{mL}$ each) enhanced the production of AICD (Figure 1(c)), a result consistent with reports by others [39, 40]. Adding ATP $(1.25 \mathrm{mM})$ to the $\gamma$-secretase/APP substrate reaction was also found to cause an average 1.6-fold increase of AICD production (Figures 1(d) and 1(e)), corroborating the report by Fraering et al. [41] who used recombinant $\gamma$ secretase solubilized from membranes of cells overexpressing the $\gamma$-secretase components. The positive effect of ATP was also obtained using $\gamma$-secretase preparations from SH-SY5Ymembranes (data not shown).

3.2. Effect of Zinc and Copper Chelators on $\gamma$-Secretase Activity. The effect of metal ion chelators and metalloprotease inhibitors on $\gamma$-secretase was evaluated using various compounds (Figures 2(a) and 2(b)). The zinc chelators, thiorphan and phosphoramidon, and the hydroxamate inhibitor ilomastat, which is an inhibitor of $\alpha$-secretase, were all assayed at $250 \mathrm{nM}$, a concentration sufficient to completely inhibit their target metalloprotease activities in cells and tissues. There was no significant effect of these compounds in the $\gamma$-secretase assay, although thiorphan showed a trend for an increase in AICD signal. Thiorphan is an inhibitor of neprilysin, which might be present in the assay as it is associated with brain membranes. The modest decrease in $\gamma$-secretase activity in the presence of the copper chelator clioquinol was not statistically significant. In contrast a $65 \%$ decrease in AICD production $(P=.024$; $N=3$ ) was observed in the presence of phenanthroline (5 mM), suggesting that some metal ions facilitate $\gamma$-secretase activity.

3.3. Metal Chelators of Broad Specificity Decrease $y$-Secretase Activity. The reduction of activity in the presence of phenanthroline led us to test the effect of EDTA, another chelator of broad specificity. Indeed, reports in the literature indicate the use of alternative buffers for in vitro $\gamma$-secretase assays. Notably, these involve the use of buffers that either contain EDTA [41, 42], or that are supplemented with $\mathrm{Ca}^{2+}$ and $\mathrm{Mg}^{2+}$ [39, 40, 43-45]. Therefore, we compared both conditions in our assay (Figures 3(a) and 3(b)). In the presence of EDTA, AICD production was $28 \%$ of that in the presence of buffer with $\mathrm{Ca}^{2+}$ and $\mathrm{Mg}^{2+}(P=.0002, N=5)$. Measurement of $\mathrm{A} \beta 40$ production by a sandwich ELISA (Figure 3(c)) showed that $0.035 \pm 0.01 \mathrm{ng} / \mathrm{mL} \mathrm{A} \beta 40$ was produced in the presence of $\mathrm{Ca}^{2+}$ and $\mathrm{Mg}^{2+}$ whereas $0.011 \pm 0.004 \mathrm{ng} / \mathrm{mL}$ was produced in the presence of EDTA, further supporting that $\mathrm{Ca}^{2+}$ and $\mathrm{Mg}^{2+}$ ions facilitate the processing of $\mathrm{C} 100$ by $\gamma$-secretase. Similar results were obtained when using solubilised SH-SY5Y membranes as the source of $\gamma$-secretase, with AICD production in the presence of EDTA being 30\% to that in the presence of $\mathrm{Ca}^{2+}$ and $\mathrm{Mg}^{2+}$ (Figures 3(d) and 3(e)). Comparing incubations with and without $\mathrm{Ca}^{2+}$ and $\mathrm{Mg}^{2+}$ showed that the addition of these metal ions ameliorates $\gamma$-secretase activity by 1.65 -fold $(P=.02, N=3)$ (Figures 3(d) and 3(e)). These data are consistent with those obtained with phenanthroline, and suggest that adding $\mathrm{Ca}^{2+}$ and $\mathrm{Mg}^{2+}$ metal ions facilitate $\gamma$-secretase cleavage of APP substrate. 


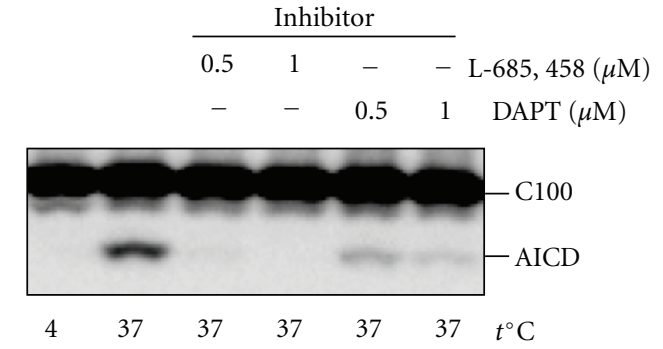

(a)

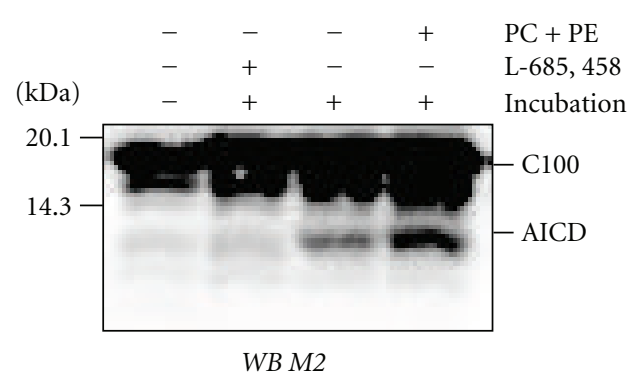

(c)

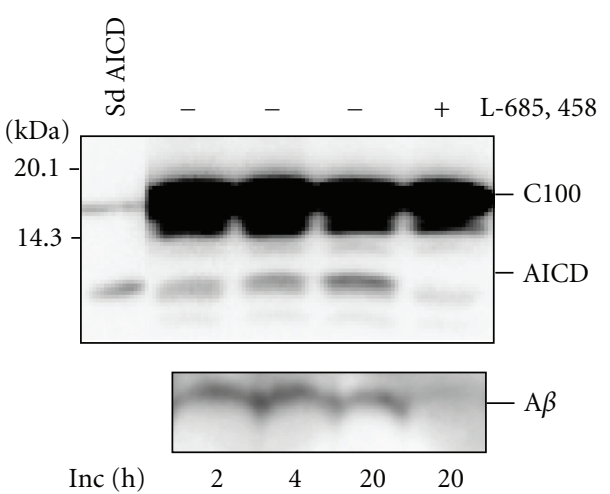

(b)

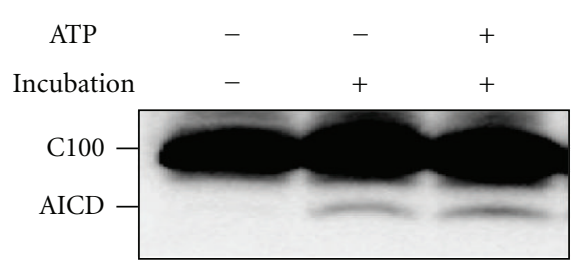

(d)

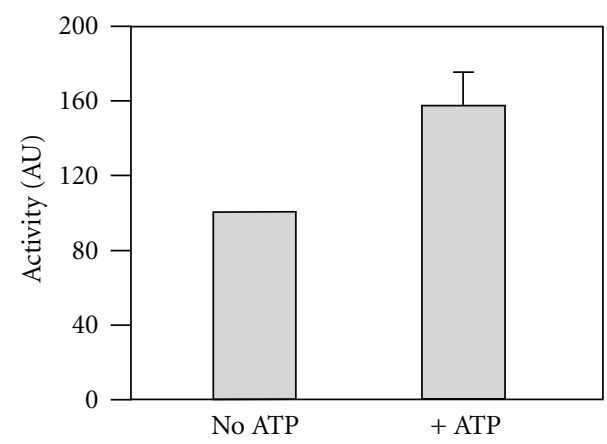

(e)

FIGURE 1: Characterization of $\gamma$-secretase in vitro assay with guinea pig brain enzyme. $\sim 1 \mu \mathrm{g}$ of purified recombinant C100-3XFLAG was incubated with $2.75 \mu \mathrm{g}$ of CHAPSO solubilised membranes of guinea pig brain in $20 \mathrm{mM}_{\mathrm{HEPES}}$ buffer, $\mathrm{pH} 7.3, \mathrm{plus} 3 \mathrm{mM} \mathrm{CaCl} 2,3 \mathrm{mM}$ $\mathrm{MgCl}_{2}$ and $150 \mathrm{mM} \mathrm{KCl}$. The reactions were stopped by adding Laemmli buffer, boiled, and separated on Tris-Tricine gels. M2 (antiFLAG) antibody and WO2 (anti-A $\beta$ 1-16) were used for western blot detection. (a) Production of an AICD fragment in the assay is inhibited by the $\gamma$-secretase inhibitors, L-685,458 and DAPT. (b) Both AICD and A $\beta$ are produced in the reaction and inhibited by L685,458 . AICD signal increases in a time dependent manner over $20 \mathrm{~h}$. A $\beta$ signal is increased at $4 \mathrm{~h}$ compared to $2 \mathrm{~h}$, but decreased at $20 \mathrm{~h}$, possibly due to degradation. (Inc, incubation at $37^{\circ} \mathrm{C}$ ). (c) Positive effect of phospholipids on AICD production in the $\gamma$-secretase assay. PC, phosphatidylcholine; PE, phosphatidylethanolamine. (d) Positive effect of ATP on the $\gamma$-secretase assay. ATP was added 1.25 mM concentration. (e) Quantitation of three separate experiments using GeneTools Syngene software shows $\sim 1.6$ fold enhancement of $\gamma$ secretase activity in the presence of $1.25 \mathrm{mM}$ ATP. The error bars represent SEM.

3.4. $\mathrm{Ca}^{2+}$ and $\mathrm{Mg}^{2+}$ Facilitate $\gamma$-Secretase Activity. To define which of $\mathrm{Ca}^{2+}$ and $\mathrm{Mg}^{2+}$ ions were important for $\gamma$-secretase activity, we tested the effect of EGTA that has much greater affinity for calcium than magnesium. In the reactions carried out with guinea pig or mouse $\gamma$-secretase activity, there were similar levels of AICD produced in the presence of EGTA than in the presence of EDTA (Figures 4(a) and 4(b)), suggesting that $\mathrm{Ca}^{2+}$ ions are required for the enhancement of $\gamma$-secretase activity. When, reactions were prepared in the presence of $2 \mathrm{mM}$ EDTA and increasing concentrations of $\mathrm{CaCl}_{2}$ or $\mathrm{MgCl}_{2}$ were added, both $\mathrm{Ca}$ and $\mathrm{Mg}$ ions individually restored AICD production to levels achieved with the $\mathrm{Ca}$ and $\mathrm{Mg}$ buffer (Figure 4(c)). However, when Mg ions were absent in the reaction, adding $3 \mathrm{mM}$ calcium resulted in precipitation of the $\mathrm{C} 100$ substrate. Therefore, both calcium and magnesium are required for optimal assay conditions. 


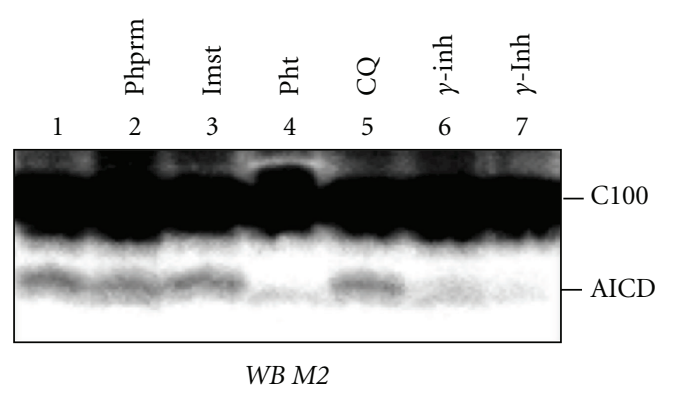

(a)

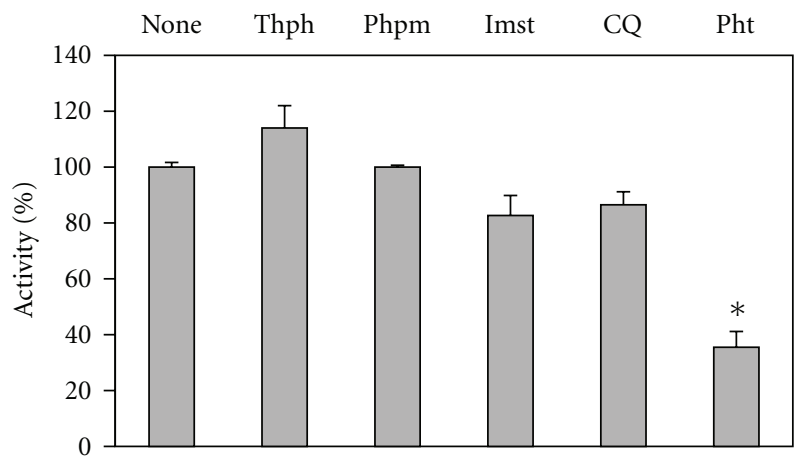

(b)

FIGURE 2: Effect of metalloprotease inhibitors, and metal chelators on $\gamma$-secretase. Chelators and inhibitors were added as DMSO solutions (final DMSO concentration 2.5\%) to the guinea pig brain $\gamma$-secretase/C100-3XFLAG reactions. (a) Representative western blot of $\gamma$-secretase assay in the presence of various inhibitors. Phpm, phosphoramidon; Ilmst, ilomastat; Pht, phenanthroline; CQ, clioquinol; $\gamma$-inh, L-685,458, used at $10 \mathrm{nM}$ (lane 6) and $100 \mathrm{nM}$ (lane 7). (b) Effect of metalloprotease inhibitors on the $\gamma$-secretase assay. Activity is expressed as the \% of substrate converted into AICD, as determined from band density analysis with GeneTools software. The error bars represent SEM. Inhibitor concentrations were selected as follows: thiorphan, $250 \mathrm{nM}$; phosphoramidon, $25 \mu \mathrm{M}$; ilomastat, $250 \mathrm{nM}$; phenanthroline, $5 \mathrm{mM}$; clioquinol, $100 \mu \mathrm{M}$.

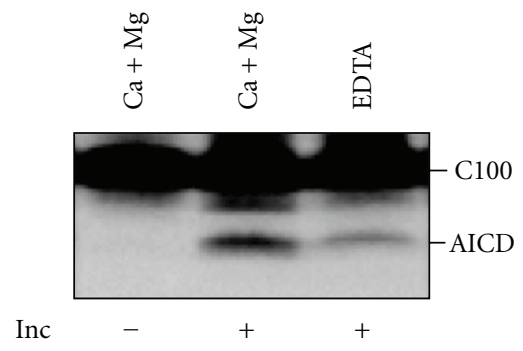

(a)

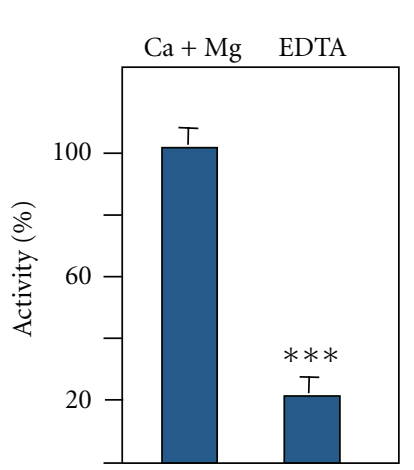

(b)

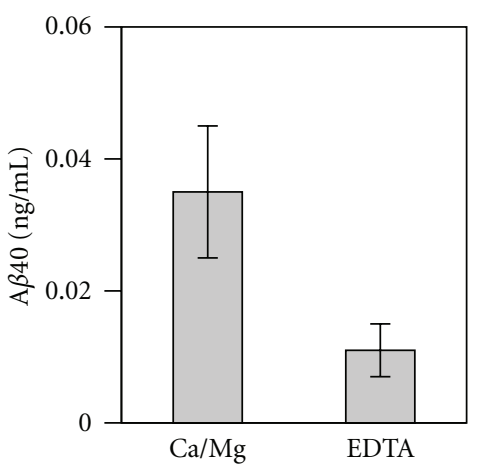

(c)

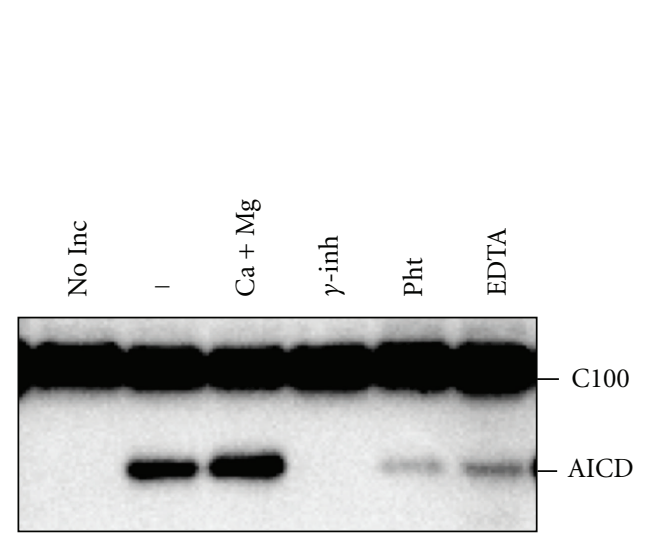

(d)

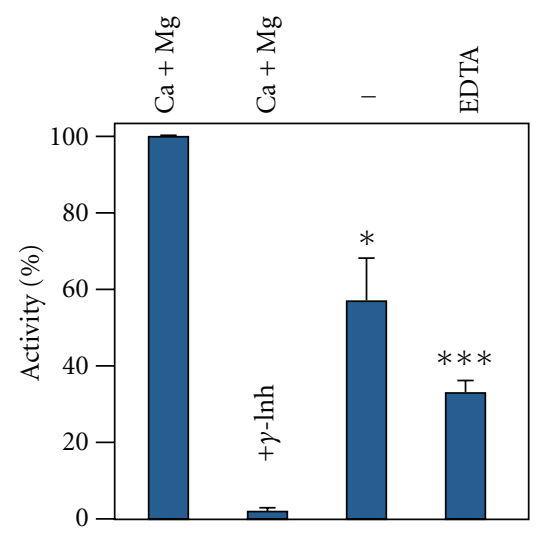

(e)

FIGURE 3: Effect of EDTA and phenanthroline on $\gamma$-secretase activity. (a) Guinea pig $\gamma$-secretase activity was assayed on C100-3XFLAG in alternate buffer conditions ( $2 \mathrm{mM}$ EDTA or $3 \mathrm{mM} \mathrm{CaCl}_{2}$ and $3 \mathrm{mM} \mathrm{MgCl}_{2}$ ). (b) Quantitative analysis of five separate experiments shows AICD production in the presence of EDTA was $28 \%$ of that produced in the presence of $\mathrm{CaCl}_{2}$, and $\mathrm{MgCl}_{2}$. (c) Quantitative analysis of A $\beta 40$ by sandwich DELFIA shows that A $\beta$ production in the presence of EDTA is lower than in the presence of $\mathrm{CaCl}_{2}$, and $\mathrm{MgCl}_{2}$. (d) $\gamma-\mathrm{Secretase}$ activity extracted from SH-SY5Y membranes was assayed in buffer conditions as indicated. Phenanthroline (Pht) concentration was $5 \mathrm{mM}$. L-685,458 was $0.5 \mu \mathrm{M}$. (e) Quantitative analysis of three blots corresponding to assays carried out as in (d) The error bars represent SEM. 


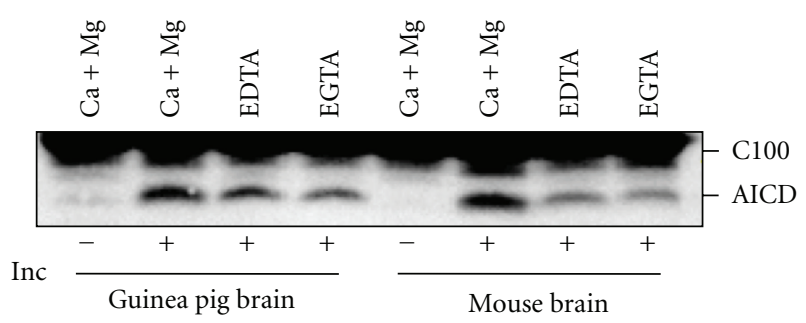

(a)

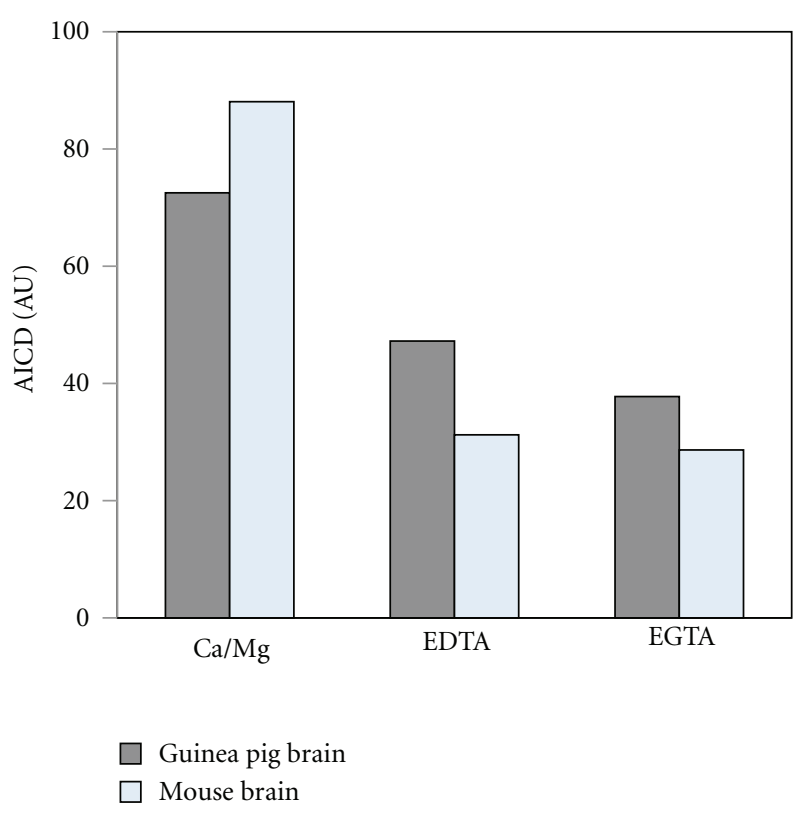

(b)

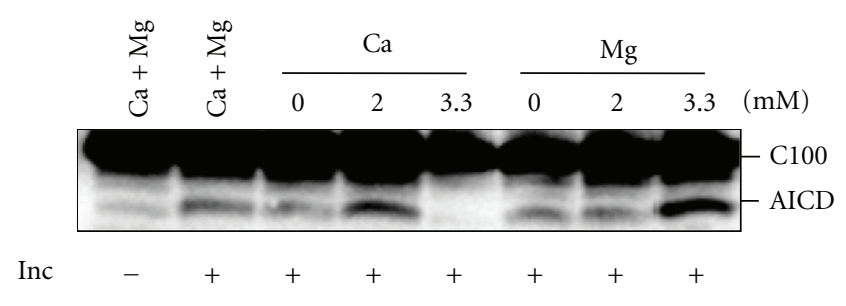

(c)

FIGURE 4: Effect of $\mathrm{Ca}^{2+}$ and $\mathrm{Mg}^{2+}$ on $\gamma$-secretase activity. (a) The effects of EDTA ( $\left.2 \mathrm{mM}\right)$ and EGTA ( 2 mM) were compared in assays carried out with $\gamma$-secretase preparations from guinea pig or mouse brains. (b) Quantitative analysis of the blot shown in (a). (c) $\gamma$-secretase assay with guinea pig brain activity was carried out in $\mathrm{HEPES}$ buffer plus $150 \mathrm{mM} \mathrm{KCl}$, in the presence of increasing $\mathrm{CaCl}_{2} \mathrm{Or} \mathrm{MgCl}_{2} \mathrm{Concentrations}$ as indicated.

3.5. Calcium and Magnesium Ions Stabilize a High Molecular Weight $\gamma$-Secretase Complex. To determine if calcium and magnesium ions had an effect on the size and stability of $\gamma$-secretase complexes, SH-SY5Y membrane-extracts diluted with $20 \mathrm{mM}$ HEPES, and $150 \mathrm{mM} \mathrm{KCl} \mathrm{(pH} \mathrm{7.3)} \mathrm{to} \mathrm{a}$ CHAPSO concentration of $0.5 \%$ were incubated in the presence of either $2 \mathrm{mM}$ EDTA, $2 \mathrm{mM} \mathrm{MgCl}_{2}$, or $2 \mathrm{mM}$ $\mathrm{CaCl}_{2}$, and analyzed by BN-PAGE and western blotting for PS1 (Figure 5(a)). In HEPES buffer, with no added calcium or magnesium, and in the presence of EDTA or EGTA, PS1 was found mostly associated with a $350 \mathrm{kDa}$ complex, and a minor amount with a $450 \mathrm{kDa}$ complex. In the incubations with $\mathrm{Mg}^{2+}$, with or without ATP, presenilin was found associated with a $\sim 450 \mathrm{kDa}$ complex and also, in a small proportion with a $1,000 \mathrm{kDa}$ complex. In the presence of $\mathrm{Ca}^{2+}$, PS1 was found mostly associated with the $\sim 450 \mathrm{kDa}$ complex. These data suggest that $\mathrm{Ca}^{2+}$ and $\mathrm{Mg}^{2+}$ ions contribute to stabilization of $\gamma$-secretase complexes, possibly in association with binding partners. Further analysis of PS1 $\gamma$-secretase complex sizes by gel filtration on a Superose6 column (Figure 5(b)) showed that, in the presence of
$\mathrm{Mg}^{2+}$ ions, most PS1 immunoreactivity is recovered in a symmetrical peak in fractions corresponding to $\sim 1,000 \mathrm{kDa}$. In the presence of EDTA, the peak of PS1 immunoreactivity was less sharp and broader, suggesting decreased complex stability.

\section{Discussion}

Biometal ions and metalloenzymes play an important role in the metabolism of APP and $\mathrm{A} \beta$, and the pharmacomodulation of copper levels in the brain represents a promising therapeutic approach to treat $\mathrm{AD}$ [18]. Little is known about the effect of metal ions on $\gamma$-secretase activity. We found that the copper-selective chelator, clioquinol did not significantly alter AICD production, suggesting that copper is not directly involved in $\gamma$-secretase cleavage of the APP substrate. This finding is consistent with our previous report that $\mathrm{CQ}$ does not alter production of $\mathrm{A} \beta$ in CHO-APP cells [28]. The zinc chelators, thiorphan and phosphoramidon, and the $\alpha$-secretase inhibitor, ilomastat, showed no significant effect on the $\gamma$-secretase reaction. 


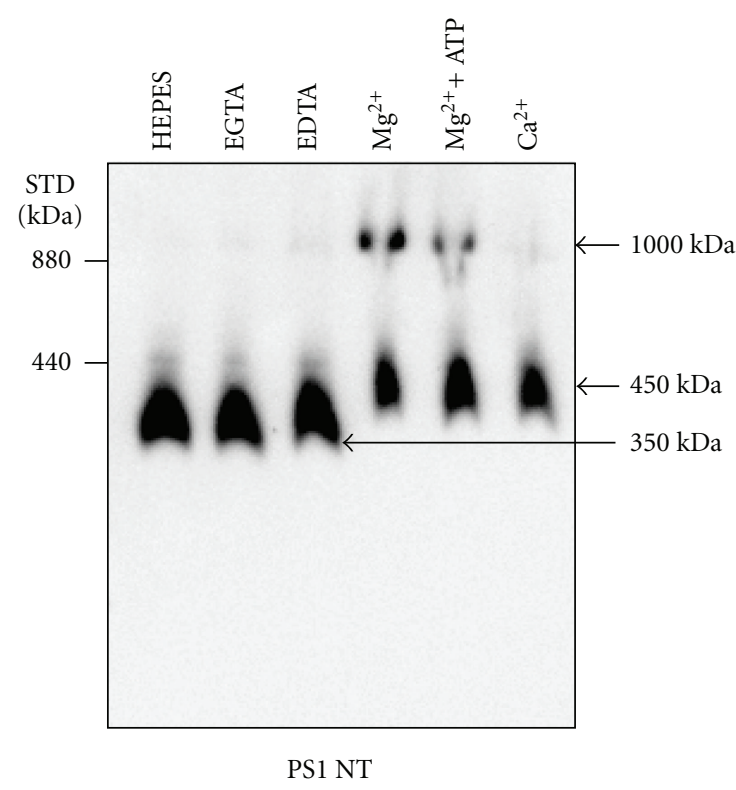

(a)

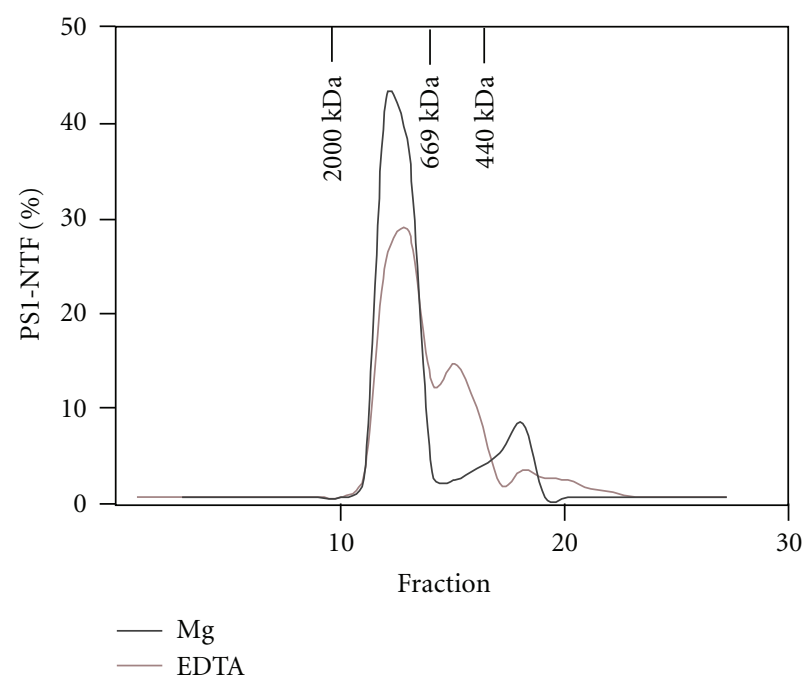

(b)

FIGURE 5: Effect of $\mathrm{Ca}^{2+}$ and $\mathrm{Mg}^{2+}$ on the size of $\gamma$-secretase complexes analyzed by BNPAGE and size-exclusion chromatography. $10 \mu \mathrm{g}$ samples of protein extract from SHSY5Y membranes were incubated with HEPES buffer, $\mathrm{pH}$ 7.3, with or without additives, as indicated. EGTA and EDTA concentrations were $2 \mathrm{mM}$. $\mathrm{CaCl}_{2}$ and $\mathrm{MgCl}_{2}$ concentrations were $3 \mathrm{mM}$. (a) The incubations were mixed with BN-PAGE sample buffer and electrophoresed on 3-8\% Tris-acetate gels. Proteins were transferred to PVDF membrane and the blot probed with antiPS1 antibody 98/1. (b) SH-SY5Y membranes (200 $\mu$ g per experiment) were extracted with $0.5 \%$ CHAPSO in buffer containing either 2 mM EDTA or $3 \mathrm{mM} \mathrm{MgCl}$. The samples were chromatographed on superose- 6 size-exclusion column and eluted fractions were analysed by western blotting with PS1 N-terminal antibody 98/1. Western blot signals were quantified and plotted against fraction numbers.

In contrast, $\gamma$-secretase activity was reduced in the presence of EDTA and phenanthroline. EGTA had an effect comparable to that of EDTA, indicating the possible involvement of calcium ions in the assay. Adding back calcium or magnesium to incubations carried out in the presence of EDTA showed that both enhanced AICD production.

In vitro $\gamma$-secretase assays described in the literature are carried out in alternative conditions, either in buffers containing EDTA $[42,46]$, or in buffers supplemented with $\mathrm{Ca}^{2+}$ and $\mathrm{Mg}^{2+}[39,40,43-45]$. The $\gamma$-secretase assays based on $\mathrm{A} \beta$ detection are usually carried out in the presence of EDTA, probably to prevent metal-dependent selfaggregation of the peptide that would interfere with antibody capture in immunoassays, whereas the assays based on western blot detection of AICD have been preferably carried out in the presence of calcium and magnesium ions. Parallel incubations in EDTA buffer and in buffer supplemented with $\mathrm{CaCl}_{2}$, and $\mathrm{MgCl}_{2}$, revealed that AICD production was lower by $70-78 \%$ in the presence of EDTA than in the presence of $\mathrm{Ca}^{2+}$ and $\mathrm{Mg}^{2+} . \mathrm{A} \beta$ levels, detected by ELISA (Figure 3(c)), were also higher in the presence of $\mathrm{Ca}^{2+}$ and $\mathrm{Mg}^{2+}$, suggesting that the same effect of these ions applies to $A \beta$ and AICD production.

To investigate whether calcium and magnesium ions influence the stability of $\gamma$-secretase complex, we used both BN-PAGE analysis and gel filtration. These techniques have been previously used to demonstrate that $\gamma$-secretase activity associates with high molecular weight complexes $[44,47]$. In the present paper, fractionation of $\gamma$-secretase preparations by BN-PAGE suggested that $\mathrm{Ca}^{2+}$ and $\mathrm{Mg}^{2+}$ ions stabilized association of PS1 with high molecular weight complexes of 1,000 and $450 \mathrm{kDa}$, compared to $350 \mathrm{kDa}$ complexes observed in the presence of EDTA and EGTA. When incubations with EDTA and without $\mathrm{Ca}^{2+}$ or $\mathrm{Mg}^{2+}$ were treated with a cross-linker prior to BN-PAGE, the $\sim 1,000$ complex was also detected in these incubations (data not shown), suggesting that this $1,000 \mathrm{kDa}$ form was normally present but was less stable through electrophoresis in the absence of $\mathrm{Ca}^{2+}$ and $\mathrm{Mg}^{2+}$ ions, and without crosslinking. Size-exclusion chromatography also suggested that $\mathrm{Mg}^{2+}$ ions stabilized HMW $\gamma$-secretase complexes. Although only the four subunits, PS, nicastrin, Aph1, and Pen-2 are required for $\gamma$-secretase activity and formation of a complex of $\sim 350 \mathrm{kDa}$, many proteins and other molecules such as phospholipid and ATP have also been shown to associate with $\gamma$-secretase complexes and to modulate their activity [48]. For instance, a recent paper reports that PION protein modulates the specificity of $\gamma$-secretase towards APP [49]. Three-dimensional reconstruction of the $\gamma$-secretase structure from electron micrographs of purified $\gamma$-secretase has shown the presence of two weak-density lateral regions [50] and it is tempting to speculate that these could accommodate metal ions. Magnesium ions form complexes with ATP and could mediate the interaction between ATP and presenilin [40]. Alternatively, calcium and magnesium 
may play an accessory role by ordering membrane phospholipids. Indeed, it has been reported that substituting EDTA-containing buffer for a buffer supplemented with calcium and magnesium help stabilize and isolate lipid rafts [51]. $\gamma$-Secretase components associate with lipid rafts, cholesterol-rich membrane regions where high $\gamma$-secretasespecific activity has been detected [52, 53]. Furthermore, experimental evidence indicates that lipids are important for $\gamma$-secretase activity [44]. Therefore, calcium and magnesium may facilitate movement of membrane domains and substrate access to the $\gamma$-secretase active site. Structural analysis by solid-state NMR and electron microscopy has demonstrated that cations modulate phospholipid bicelle size and that $\mathrm{MgCl}_{2}$ and $\mathrm{CaCl}_{2}$ stabilize large diameter (500 $\AA$ ) bicelle discs [54]. Thus, the increase in molecular mass of $\gamma$-secretase that was observed when adding divalent cations may be consistent with the association of a larger number of detergent and phospholipid molecules with the $\gamma$-secretase complex.

Considering that $\mathrm{A} \beta$ has been shown to form membrane pores and disrupt neuronal calcium homeostasis by increasing $\mathrm{Ca}^{2+}$ influx [55], elevated $\mathrm{A} \beta$ could contribute to increased intraneuronal $\left[\mathrm{Ca}^{2+}\right]$ that might in turn increase $\gamma$-secretase activity and $\mathrm{A} \beta$ production. Thus, it will be important to clarify how calcium and magnesium tune $\gamma$ secretase activity as this may have potential implications in $\mathrm{AD}$ pathogenesis.

\section{Conclusions}

Our study indicates that copper and zinc chelators have no direct effect on $\gamma$-secretase activity in vitro. It also demonstrates that chelators of broad specificity decrease cleavage of APP C100 substrate. Furthermore, it shows that $\mathrm{Ca}^{2+}$ and $\mathrm{Mg}^{2+}$ ions facilitate AICD production and contribute to stabilizing HMW $\gamma$-secretase complexes. This finding suggests that $\mathrm{Ca}^{2+}$ and $\mathrm{Mg}^{2}$ mediate molecular associations that modulate $\gamma$-secretase activity.

\section{Abbreviations}

A $\beta: \quad$ amyloid- $\beta$ peptide

AICD: $\quad$ APP intracellular domain

APP: $\quad$ amyloid- $\beta$ precursor protein

ATP: $\quad$ adenosine $5^{\prime}$-triphosphate

BN-PAGE: blue native polyacrylamide gel electrophoresis

C99: $\quad 99$ amino acid carboxyl terminal fragment of APP

CHAPSO: [3-[(3-cholamidopropyl)dimethylammonio-]2-hydroxy-1-propanesulfonate]

CTF: C-terminal fragment

CQ: $\quad$ 5-chloro7-iodo-8-hydroxyquinoline, or clioquinol

DMSO: dimethyl sulfoxide

DSP: dithiobis[succinimidylpropionate]

EGTA: ethylene glycol-bis[2-aminoethyl ether]-N,N, $\mathrm{N}^{\prime}, \mathrm{N}^{\prime}$-tetraacetic acid

HEPES: $\quad \mathrm{N}$-(2-hydroxyethyl)piperazine- $\mathrm{N}^{\prime}-2-$ ethanesulfonic acid
MMP: matrix metalloprotease

PC: phosphatidylcholine

PE: phosphotidyl-ethanolamine

PS: presenilin

PVDF: polyvinylidene fluoride

SDS: sodium dodecylsulfate.

\section{Acknowledgments}

This study was supported in part by the Australian NHMRC (project Grants 400073 and 566520 to G. Evin and J. G. Culvenor). The authors thank Barbara Solchenberger for technical help with some parts of the study and Katrina Laughton for A $\beta$ ELISA.

\section{References}

[1] G. Evin, M. F. Sernee, and C. L. Masters, "Inhibition of $\gamma$ secretase as a therapeutic intervention for Alzheimer's disease: prospects, limitations and strategies," CNS Drugs, vol. 20, no. 5, pp. 351-372, 2006.

[2] J. Kang, H.-G. Lemaire, A. Unterbeck et al., "The precursor of Alzheimer's disease amyloid A4 protein resembles a cellsurface receptor," Nature, vol. 325, no. 6106, pp. 733-736, 1987.

[3] R. Vassar, "BACE1: the $\beta$-secreiase enzyme in Alzheimer's disease," Journal of Molecular Neuroscience, vol. 23, no. 1-2, pp. 105-113, 2004.

[4] A. Weidemann, S. Eggert, F. B. M. Reinhard et al., "A novel $\varepsilon$-cleavage within the transmembrane domain of the Alzheimer amyloid precursor protein demonstrates homology with Notch processing," Biochemistry, vol. 41, no. 8, pp. 28252835, 2002.

[5] X. Cao and T. C. Südhof, "A transcriptivety active complex of APP with Fe65 and histone acetyltransferase Tip60," Science, vol. 293, no. 5527, pp. 115-120, 2001.

[6] G. Zhao, M. Z. Cui, G. Mao et al., " $y$-cleavage is dependent on $\zeta$-cleavage during the proteolytic processing of amyloid precursor protein within its transmembrane domain," Journal of Biological Chemistry, vol. 280, no. 45, pp. 37689-37697, 2005.

[7] Y. Qi-Takahara, M. Morishima-Kawashima, Y. Tanimura et al., "Longer forms of amyloid $\beta$ protein: implications for the mechanism of intramembrane cleavage by $\gamma$-secretase," Journal of Neuroscience, vol. 25, no. 2, pp. 436-445, 2005.

[8] G. Evin and A. Weidemann, "Biogenesis and metabolism of Alzheimer's disease A $\beta$ amyloid peptides," Peptides, vol. 23, no. 7, pp. 1285-1297, 2002.

[9] T. Iwatsubo, "The $\gamma$-secretase complex: machinery for intramembrane proteolysis," Current Opinion in Neurobiology, vol. 14, no. 3, pp. 379-383, 2004.

[10] B. De Strooper, P. Saftig, K. Craessaerts et al., "Deficiency of presenilin-1 inhibits the normal cleavage of amyloid precursor protein," Nature, vol. 391, no. 6665, pp. 387-390, 1998.

[11] M. S. Wolfe, W. Xia, B. L. Ostaszewski, T. S. Diehl, W. T. Kimberly, and D. J. Selkoe, "Two transmembrane aspartates in presenilin-1 required for presenilin endoproteolysis and $\gamma$ secretase activity," Nature, vol. 398, no. 6727, pp. 513-517, 1999. 
[12] A. I. Bush, G. Multhaup, R. D. Moir et al., "A novel zinc(II) binding site modulates the function of the $\beta A 4$ amyloid protein precursor of Alzheimer's disease," Journal of Biological Chemistry, vol. 268, no. 22, pp. 16109-16112, 1993.

[13] A. I. Bush, W. H. Pettingell, M. D. Paradis, and R. E. Tanzi, "Modulation of $\mathrm{A} \beta$ adhesiveness and secretase site cleavage by zinc," Journal of Biological Chemistry, vol. 269, no. 16, pp. 12152-12158, 1994.

[14] L. Hesse, D. Beher, C. L. Masters, and G. Multhaup, "The $\beta$ A4 amyloid precursor protein binding to copper," FEBS Letters, vol. 349, no. 1, pp. 109-116, 1994.

[15] G. Multhaup, A. Schlicksupp, L. Hesse et al., "The amyloid precursor protein of Alzheimer's disease in the reduction of copper(II) to copper(I)," Science, vol. 271, no. 5254, pp. 1406 1409, 1996.

[16] A. R. White, G. Multhaup, F. Maher et al., "The Alzheimer's disease amyloid precursor protein modulates copper-induced toxicity and oxidative stress in primary neuronal cultures," Journal of Neuroscience, vol. 19, no. 21, pp. 9170-9179, 1999.

[17] X. Huang, C. S. Atwood, M. A. Hartshorn et al., "The A $\beta$ peptide of Alzheimer's disease directly produces hydrogen peroxide through metal ion reduction," Biochemistry, vol. 38, no. 24, pp. 7609-7616, 1999.

[18] P. J. Crouch, A. R. White, and A. I. Bush, "The modulation of metal bio-availability as a therapeutic strategy for the treatment of Alzheimer's disease," FEBS Journal, vol. 274, no. 15, pp. 3775-3783, 2007.

[19] R. A. Cherny, C. S. Atwood, M. E. Xilinas et al., "Treatment with a copper-zinc chelator markedly and rapidly inhibits $\beta$-amyloid accumulation in Alzheimer's disease transgenic mice," Neuron, vol. 30, no. 3, pp. 665-676, 2001.

[20] D. J. Selkoe, "Clearing the brain's amyloid cobwebs," Neuron, vol. 32, no. 2, pp. 177-180, 2001.

[21] A. Mukherjee, E. S. Song, M. Kihiko-Ehmann et al., "Insulysin hydrolyzes amyloid $\beta$ peptides to products that are neither neurotoxic nor deposit on amyloid plaques," Journal of Neuroscience, vol. 20, no. 23, pp. 8745-8749, 2000.

[22] V. Chesneau, K. Vekrellis, M. R. Rosner, and D. J. Selkoe, "Purified recombinant insulin-degrading enzyme degrades amyloid $\beta$-protein but does not promote its oligomerization," Biochemical Journal, vol. 351, no. 2, pp. 509-516, 2000.

[23] D. Edbauer, M. Willem, S. Lammich, H. Steiner, and C. Haass, "Insulin-degrading enzyme rapidly removes the $\beta$-amyloid precursor protein intracellular domain (AICD)," Journal of Biological Chemistry, vol. 277, no. 16, pp. 13389-13393, 2002.

[24] W. Farris, S. Mansourian, Y. Chang et al., "Insulin-degrading enzyme regulates the levels of insulin, amyloid $\beta$-protein, and the $\beta$-amyloid precursor protein intracellular domain in vivo," Proceedings of the National Academy of Sciences of the United States of America, vol. 100, no. 7, pp. 4162-4167, 2003.

[25] N. Iwata, S. Tsubuki, Y. Takaki et al., "Identification of the major $\mathrm{A} \beta$-degrading catabolic pathway in brain parenchyma: suppression leads to biochemical and pathological deposition," Nature Medicine, vol. 6, no. 2, pp. 143-150, 2000.

[26] R. A. Marr, H. Guan, E. Rockenstein et al., "Neprilysin regulates amyloid $\beta$ peptide levels," Journal of Molecular Neuroscience, vol. 22, no. 1-2, pp. 5-11, 2004.

[27] K. Shirotani, S. Tsubuki, N. Iwata et al., "Neprilysin degrades both amyloid $\beta$ peptides 1-40 and 1-42 most rapidly and efficiently among thiorphan- and phosphoramidon-sensitive endopeptidases," Journal of Biological Chemistry, vol. 276, no. 24, pp. 21895-21901, 2001.
[28] A. R. White, T. Du, K. M. Laughton et al., "Degradation of the Alzheimer disease amyloid $\beta$-peptide by metal-dependent up-regulation of metalloprotease activity," Journal of Biological Chemistry, vol. 281, no. 26, pp. 17670-17680, 2006.

[29] K. J. Yin, J. R. Cirrito, P. Yan et al., "Matrix metalloproteinases expressed by astrocytes mediate extracellular amyloid$\beta$ peptide catabolism," Journal of Neuroscience, vol. 26, no. 43, pp. 10939-10948, 2006.

[30] P. Yan, X. Hu, H. Song et al., "Matrix metalloproteinase9 degrades amyloid- $\beta$ fibrils in vitro and compact plaques in situ," Journal of Biological Chemistry, vol. 281, no. 34, pp. 24566-24574, 2006.

[31] S. Lammich, E. Kojro, R. Postina et al., "Constitutive and regulated $\alpha$-secretase cleavage of Alzheimer's amyloid precursor protein by a disintegrin metalloprotease," Proceedings of the National Academy of Sciences of the United States of America, vol. 96, no. 7, pp. 3922-3927, 1999.

[32] B. Angeletti, K. J. Waldron, K. B. Freeman et al., "BACE1 cytoplasmic domain interacts with the copper chaperone for superoxide dismutase-1 and binds copper," Journal of Biological Chemistry, vol. 280, no. 18, pp. 17930-17937, 2005.

[33] D. E. Hoke, J. L. Tan, N. T. Ilaya et al., "In vitro $\gamma$-secretase cleavage of the Alzheimer's amyloid precursor protein correlates to a subset of presenilin complexes and is inhibited by zinc," FEBS Journal, vol. 272, no. 21, pp. 5544-5557, 2005.

[34] A. J. George, R. M. D. Holsinger, C. A. McLean et al., "APP intracellular domain is increased and soluble $A \beta$ is reduced with diet-induced hypercholesterolemia in a transgenic mouse model of Alzheimer disease," Neurobiology of Disease, vol. 16, no. 1, pp. 124-132, 2004.

[35] G. Evin, L. D. Canterford, D. E. Hoke, R. A. Sharples, J. G. Culvenor, and C. L. Masters, "Transition-state analogue $\gamma$ secretase inhibitors stabilize a $900 \mathrm{kDa}$ presenilin/nicastrin complex," Biochemistry, vol. 44, no. 11, pp. 4332-4341, 2005.

[36] J. G. Culvenor, G. Evin, M. A. Cooney et al., "Presenilin 2 expression in neuronal cells: induction during differentiation of embryonic carcinoma cells," Experimental Cell Research, vol. 255, no. 2, pp. 192-206, 2000.

[37] M. S. Shearman, D. Beher, E. E. Clarke et al., "L-685,458, an aspartyl protease transition state mimic, is a potent inhibitor of amyloid $\beta$-protein precursor $\gamma$-secretase activity," Biochemistry, vol. 39, no. 30, pp. 8698-8704, 2000.

[38] H. F. Dovey, V. John, J. P. Anderson et al., "Functional $\gamma$ secretase inhibitors reduce $\beta$-amyloid peptide levels in brain," Journal of Neurochemistry, vol. 76, no. 1, pp. 173-181, 2001.

[39] P. C. Fraering, W. Ye, J. M. Strub et al., "Purification and characterization of the human $\gamma$-secretase complex," Biochemistry, vol. 43, no. 30, pp. 9774-9789, 2004.

[40] J. D. J. Wrigley, I. Schurov, E. J. Nunn et al., "Functional overexpression of $\gamma$-secretase reveals protease-independent trafficking functions and a critical role of lipids for protease activity," Journal of Biological Chemistry, vol. 280, no. 13, pp. 12523-12535, 2005.

[41] P. C. Fraering, W. Ye, M. J. LaVoie, B. L. Ostaszewski, D. J. Selkoe, and M. S. Wolfe, " $\gamma$-secretase substrate selectivity can be modulated directly via interaction with a nucleotidebinding site," Journal of Biological Chemistry, vol. 280, no. 51, pp. 41987-41996, 2005.

[42] D. Beher, M. Fricker, A. Nadin et al., "In vitro characterization of the presenilin-dependent $\gamma$-secretase complex using a novel affinity ligand," Biochemistry, vol. 42, no. 27, pp. 8133-8142, 2003. 
[43] S. Shah, S. F. Lee, K. Tabuchi et al., "Nicastrin functions as a $\gamma$ secretase-substrate receptor," Cell, vol. 122, no. 3, pp. 435-447, 2005.

[44] Y. M. Li, M. T. Lai, M. Xu et al., "Presenilin 1 is linked with $\gamma$-secretase activity in the detergent solubilized state," Proceedings of the National Academy of Sciences of the United States of America, vol. 97, no. 11, pp. 6138-6143, 2000.

[45] W. T. Kimberly, W. P. Esler, W. Ye et al., "Notch and the amyloid precursor protein are cleaved by similar $\gamma$ secretase(s)," Biochemistry, vol. 42, no. 1, pp. 137-144, 2003.

[46] G. Tian, S. V. Ghanekar, D. Aharony et al., "The mechanism of $\gamma$-secretase: multiple inhibitor binding sites for transition state analogs and small molecule inhibitors," Journal of Biological Chemistry, vol. 278, no. 31, pp. 28968-28975, 2003.

[47] T. Ogura, K. Mio, I. Hayashi et al., "Three-dimensional structure of the ${ }^{3}$-secretase complex," Biochemical and Biophysical Research Communications, vol. 343, no. 2, pp. 525-534, 2006.

[48] T. Wakabayashi, K. Craessaerts, L. Bammens et al., "Analysis of the $\gamma$-secretase interactome and validation of its association with tetraspanin-enriched microdomains," Nature Cell Biology, vol. 11, no. 11, pp. 1340-1346, 2009.

[49] G. He, W. Luo, P. Li et al., " $\gamma$-secretase activating protein is a therapeutic target for Alzheimer's disease," Nature, vol. 467, no. 7311, pp. 95-98, 2010.

[50] V. K. Lazarov, P. C. Fraering, W. Ye, M. S. Wolfe, D. J. Selkoe, and $\mathrm{H}$. Li, "Electron microscopic structure of purified, active $\gamma$-secretase reveals an aqueous intramembrane chamber and two pores," Proceedings of the National Academy of Sciences of the United States of America, vol. 103, no. 18, pp. 6889-6894, 2006.

[51] J. L. Macdonald and L. J. Pike, "A simplified method for the preparation of detergent-free lipid rafts," Journal of Lipid Research, vol. 46, no. 5, pp. 1061-1067, 2005.

[52] S. Wahrle, P. Das, A. C. Nyborg et al., "Cholesterol-dependent $\gamma$-secretase activity in buoyant cholesterol-rich membrane microdomains," Neurobiology of Disease, vol. 9, no. 1, pp. 1123, 2002.

[53] Y. Urano, I. Hayashi, N. Isoo et al., "Association of active $\gamma$ secretase complex with lipid rafts," Journal of Lipid Research, vol. 46, no. 5, pp. 904-912, 2005.

[54] A. Arnold, T. Labrot, R. Oda, and E. J. Dufourc, "Cation modulation of bicelle size and magnetic alignment as revealed by solid-state NMR and electron microscopy," Biophysical Journal, vol. 83, no. 5, pp. 2667-2680, 2002.

[55] D. H. Small, R. Gasperini, A. J. Vincent, A. C. Hung, and L. Foa, "The role of $\mathrm{A} \beta$-induced calcium dysregulation in the pathogenesis of Alzheimer's disease," Journal of Alzheimer's Disease, vol. 16, no. 2, pp. 225-233, 2009. 


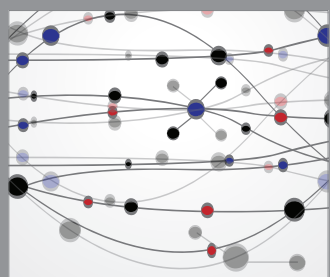

The Scientific World Journal
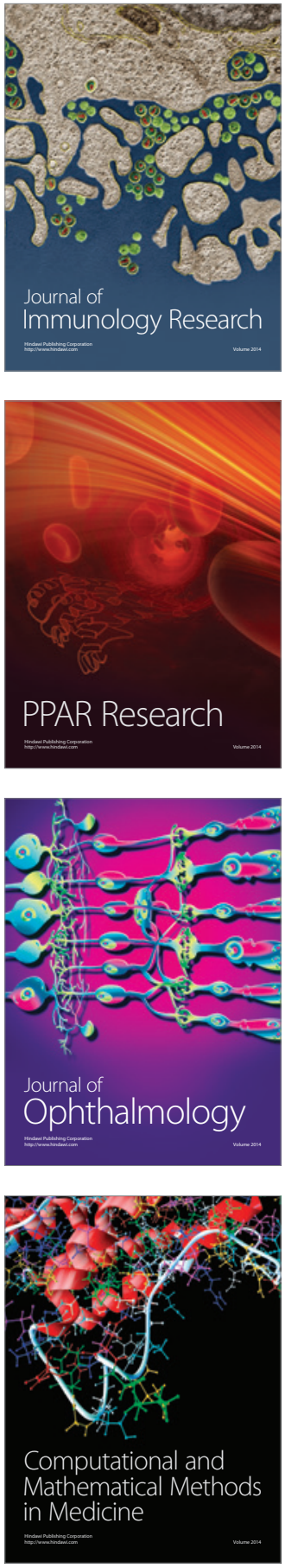

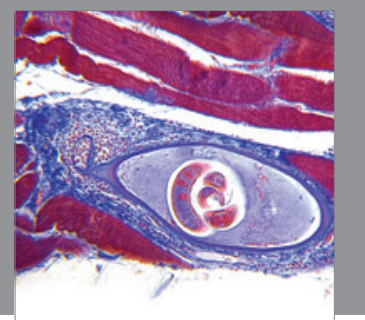

Gastroenterology

Research and Practice
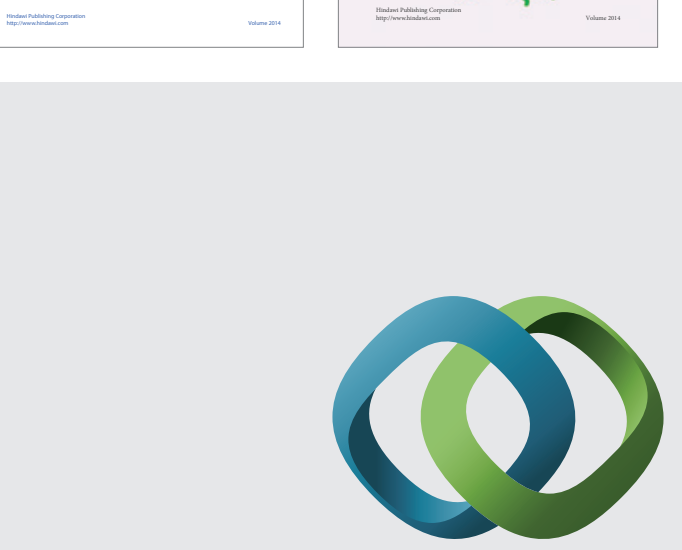

\section{Hindawi}

Submit your manuscripts at

http://www.hindawi.com
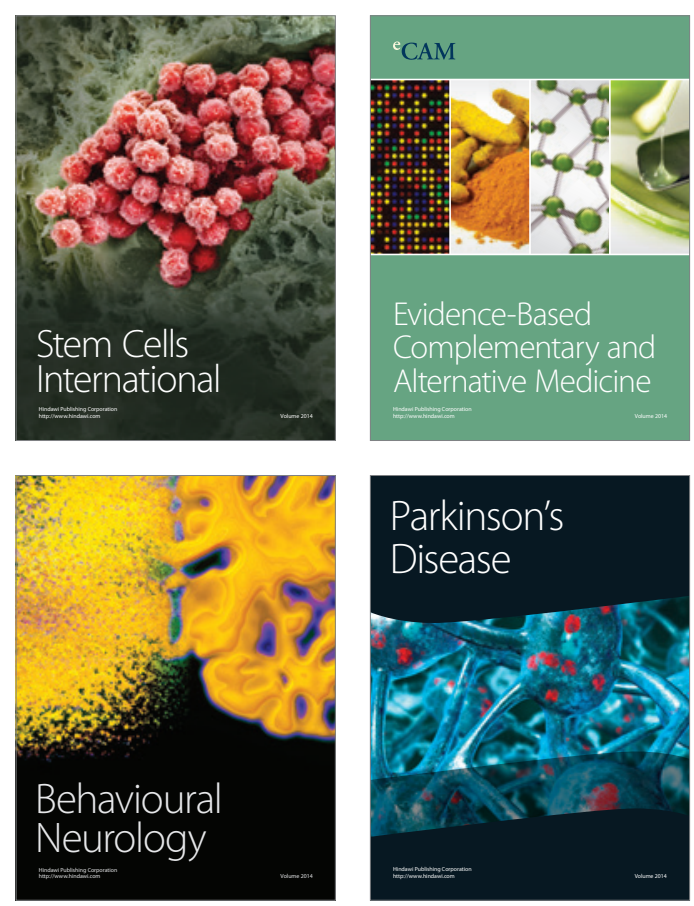

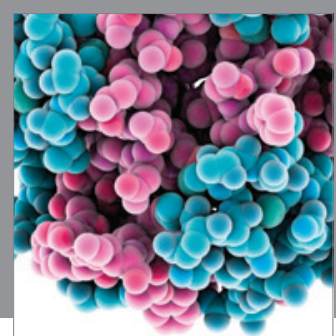

Journal of
Diabetes Research

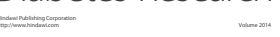

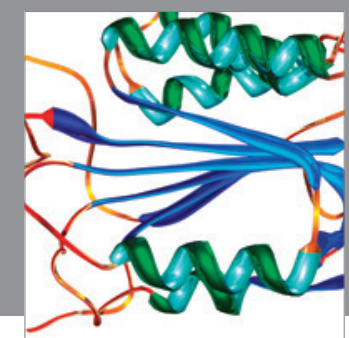

Disease Markers
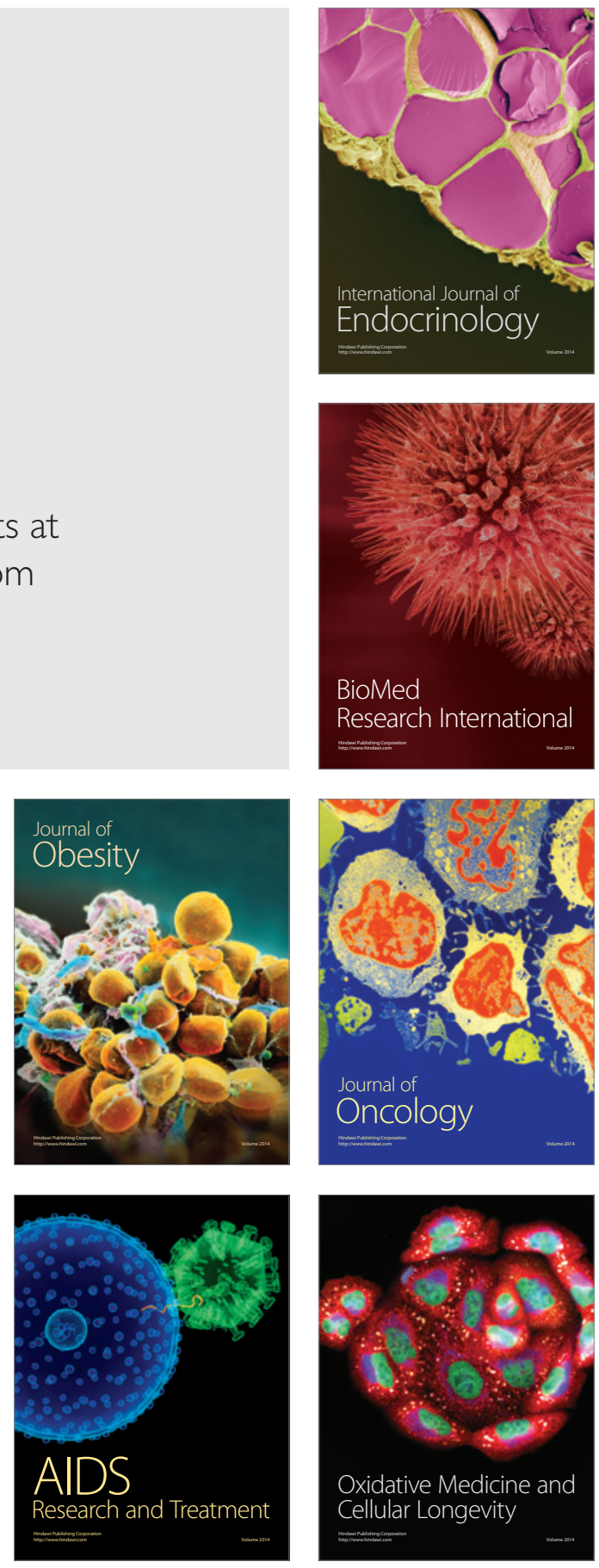